Research Article

\title{
Genetic Variability, Heritability, and Genetic Advance Estimates in Garlic (Allium sativum) from the Gamo Highlands of Southern Ethiopia
}

\author{
Azene Tesfaye \\ Arba Minch University, Arba Minch, Ethiopia \\ Correspondence should be addressed to Azene Tesfaye; azet567@gmail.com
}

Received 1 July 2021; Revised 16 September 2021; Accepted 15 October 2021; Published 21 October 2021

Academic Editor: Othmane Merah

Copyright (c) 2021 Azene Tesfaye. This is an open access article distributed under the Creative Commons Attribution License, which permits unrestricted use, distribution, and reproduction in any medium, provided the original work is properly cited.

\begin{abstract}
Genetic variability is the fundamental requirement for any plant breeding program to develop a superior cultivar. This study aimed to estimate the genetic variability and determine the correlation between the various quantitative characteristics of garlic accessions. The experiment was carried out in the Ezo-Otte area of the Chencha district in the Gamo highlands of southern Ethiopia and 28 garlic accessions were evaluated in a Randomized Complete Block Design with three replicates. Various morphological descriptors were measured to evaluate the variability and correlation coefficients. The analysis of variance showed a highly significant variation for all characters, which indicates greater variability in the accession. High and moderate heritability in broad sense estimates were obtained for the majority of the traits examined. Days to maturity (28.09), bulb weight (22.33), and bulb diameter (equatorial) (21.33) showed higher genetic advance. The maximum value of the genetic progress as a percentage of the mean was observed in bulb yield, clove weight, bulb diameter (equatorial), and number of leaves. In addition, bulb diameter (equatorial), clove weight, bulb weight, and plant height were observed to be highly hereditary coupled with high genetic advance as a percentage of the mean, suggesting that they can be improved by direct selection. Coefficient analysis has shown that maximum attention should be paid to bulb diameter (equatorial), the number of cloves, bulb diameter (equatorial), bulb weight, plant height, and leaf length, as these traits also correlate positively and significantly with bulb yield.
\end{abstract}

\section{Introduction}

Garlic (Allium sativum L.) is a diploid $(2 n=2 x=16)$ bulbous plant that belongs to the Amaryllidaceae family and has enormous value in human life [1]. The cultivated plant originates from Central Asia and is cultivated all over the world for culinary, medicinal, and religious purposes [2]. The presence of sulfur compounds contributes to its medicinal properties. Garlic is mainly propagated vegetatively through mandatory apomixis by planting individual cloves [3]. The plant grows well in well-drained sandy or silty clay soils with a pH of 7 and good moisture storage properties [4].

Garlic plays an important role in human life. Its nutritional and medical benefits are undisputed [5-7]. From a nutritional point of view, it is used as a dietary supplement, spice, and source of vitamins $[8,9]$. In addition, due to the presence of sulfur compounds, biological agents (allicin), and other derivatives, garlic has the potential to boost the immune system to treat human diseases [10] including hypertension, infections, viral infections, cancer, hypertension snakebites, malaria, wound infection, cold, malaria, cough, pulmonary tuberculosis, high blood pressure, venereal diseases, mental illness, kidney disease, liver disease, asthma, and diabetes, as well as cell death against free radicals, and some cultures have used it to ward off evil spirits [9]. It also nourishes and supports the heart, stomach, circulation, and lungs $[6,11]$.

In Ethiopia, garlic is produced by small and commercial growers for a variety of purposes, such as home consumption, herbal medicine, and cooking flavoring, as well as 
a source of income for many smallholders. The average area and total production of garlic in Ethiopia are 16,411.19 ha and 159,093.58 tons annually, respectively [4]. Chencha is one of the largest garlic producers in the Gamo highlands in southern Ethiopia due to its weather conditions, the availability of water, and the fertility of the soil. Although the environmental conditions favor the garlic productivity, several biotic and abiotic factors hinder plant productivity and lead to yield losses, for example, lack of appropriate plant material, inappropriate agronomic practices, fungal diseases, lack of adequate insecticides and pesticides, and a poor marketing system. However, garlic productivity is still low in the area. In particular, no attempt has been made to improve garlic production based on the available genetic diversity between different cultivated accessions in order to fully exploit the yield potential of the crop.

Recent genetic studies have shown that garlic varies widely under different ecological conditions and that some accessions have adapted to specific environments through artificial and natural selection [12]. Genetic diversity has been found in cultivated garlic for 16 different morphological traits [6]. Similarly, variations in bulb weight, coat layer, and leaf length assessed 24 garlic ecotypes [13]. These examples suggest that assessing the genetic diversity of garlic is important for selection and breeding purposes. Studying the genetic variation in cultivated garlic accessions is very useful, as it can lead to the identification of suitable varieties through clonal selection and accession with fertile florets for use in inheritable breeding programs. In particular, the improvement in plant production is based on the available genetic variability and the extent to which the desirable traits are inheritable [14]. Studies of genetic variability with the help of suitable genetic parameters are therefore indispensable for an effective breeding program $[5,15]$. The yield is a very complex unit that is influenced by several yield components that are sensitive to environmental fluctuations [16]. Thus, the selection according to income components has a better chance of success. Therefore, it is necessary to know the type and nature of yield components and their interrelationships. The evaluation of the genetic resources of garlic through morphoagronomic descriptors will allow us to understand the differences between the accessions and to select those with our interested character for the breeding program. Information on the nativeness and extent of genetic variability in genetic stocks, heritability, and genetic advance of various traits will be of great use for future breeding programs. With all of these facts in mind, this research was conducted to assess the genetic variability and association between bulb yield and related traits in garlic access from the Gamo highlands in southern Ethiopia.

\section{Methods and Materials}

2.1. Description of the Study Area. The experiment was carried out on leased farmland in Ezo-Otte kebele $(3,150 \mathrm{~m}$ above sea level, GPS $72 \mathrm{H}$ Garmin), highland parts of the Chencha district, during the 2017 harvest season. Chencha district is about $530 \mathrm{~km}$ and $303 \mathrm{~km}$ from Addis Ababa, the capital of Ethiopia, and Awasa, the capital of the Southern
Nations and Nationalities and People Regional State (SNNPR). It is also located between $608^{\prime} 55^{\prime \prime}$ to $6025^{\prime} 30^{\prime \prime} \mathrm{N}$ and $37^{\circ} 29^{\prime} 57^{\prime \prime}$ to $37039^{\prime} 36^{\prime \prime} \mathrm{E}$. Its altitude is between 1300 and $3250 \mathrm{~m}$ above sea level [17]. The agroecology of Chencha is classified as highlands ( $>2500 \mathrm{~m}$ above sea level), which makes up $82 \%$ of the total area, and midland (2000-2500 m above sea level) with a share of $18 \%$. The minimum air temperature ranges from 11 to $13^{\circ} \mathrm{C}$, while the maximum air temperature ranges from 18 to $24^{\circ} \mathrm{C}$. Based on 8 -year data (2002-2009) from the district's Department of Agriculture, the average annual rainfall is $1172 \mathrm{~mm}$, with a peak in April followed by a second peak in September. As a result of this bimodal rainfall pattern, there are two harvest seasons known locally as Belg (March to May) and Meher (June to October) [18].

\subsection{Plant Materials and Experimental Design.}

Twenty-eight garlic accessions (20 accessions were collected from the Debre Zeit Agricultural Research Center and 8 accessions from the Chencha district), selected based on productivity, availability, and some tolerance to biotic stress in the respected area, were included in the study (Table 1). Due to the scarcity of available plant material and experimental farmland, research was limited to these accessions. The physical-chemical analysis of the soil was examined.

2.3. Experimental Design and Field Management. The garlic accessions were planted in a Randomized Complete Block Design (RCBD) with three replicates in the 2017 cropping/ Meher season at Ezo-Otte, Chencha, Gamo highlands of southern Ethiopia. The plot size was $2 \mathrm{~m} \times 1 \mathrm{~m}$ with 5 rows of $2 \mathrm{~m}$ in length and $10 \mathrm{~cm}$ between plants within a row and $20 \mathrm{~cm}$ between rows [6,7]. All other agronomic practices were applied uniformly to the entire plot, as recommended $[7,19]$.

2.4. Data Collection. Morphological traits were measured at different growth stages according to descriptors for garlic developed by the International Plant Genetic Resources Institute (IPGRI) [20]. Data on days to germination $(50 \%$ emergence), plant height, number of shoots per plant, number of leaves per plant, leaf length, cloves per bulb, maturity time, bulb length, bulb diameter (equatorial), dry weight of the bulb, and the plant yield were recorded from a sample of five representative plants. The bulb dry weight was measured after harvest, once the plants were dried. The bulb yield was recorded from the middle 4 rows of each plot and converted to tons per hectare. $50 \%$ germination/emergence was recorded when $50 \%$ of the plants per plot had emerged. The maturity time was recorded when the plant was ready for harvest [2].

2.5. Data Analysis. For each treatment, the mean of the parameters described above was calculated and subjected to analysis of variance using SAS computer software version 9.0 with a general linear model method. The mean value separation test was carried out by an LSD test (Least Significant Difference) with a probability level of 5\% [21]. 
TABLE 1: Description of the garlic germplasm included in the study, Gamo highlands, southern Ethiopia, 2017.

\begin{tabular}{lccc}
\hline Accession code & Collection site & Accession code & Collection site \\
\hline Gidole (G-1) & Gidole & DZtg043/06 (G-14) & Debre Zeit Research Center \\
Zagie (G-2) & Zagie & DZtg051/06 (G-15) & Debre Zeit Research Center \\
Geresse (G-3) & Geresse & DZtg080/06 (G-16) & Debre Zeit Research Center \\
Zeme (G-4) & Zeme & DZtg085/06 (G-17) & Debre Zeit Research Center \\
Durbe (G-5) & Durbe & DZtg088/06 (G-18) & Debre Zeit Research Center \\
DZtg002/06 (G-6) & Debre Zeit Research Center & DZtg102/06 (G-19) & Debre Zeit Research Center \\
DZtg009/06 (G-7) & Debre Zeit Research Center & DZtg109/06 (G-20) & Debre Zeit Research Center \\
DZtg011/06 (G-8) & Debre Zeit Research Center & DZtg120/06 (G-21) & Debre Zeit Research Center \\
DZtg013/06 (G-9) & Debre Zeit Research Center & Ztg123/06 (G-22) & Debre Zeit Research Center \\
DZtg015/06 (G-10) & Debre Zeit Research Center & DZtg129/06 (G-23) & Debre Zeit Research Center \\
DZtg017/06 (G-11) & Debre Zeit Research Center & DZtg135/06 (G-24) & Debre Zeit Research Center \\
DZtg018/06 (G-12) & Debre Zeit Research Center & DZtg141/06 (G-25) & Debre Zeit Research Center \\
DZtg025/06 (G-13) & Debre Zeit Research Center & H01/06 (G-26) & Bonke \\
& & H02/06 (G-27) & Gircha \\
& & Dita51 (G-28) & Dita \\
\hline
\end{tabular}

2.6. Estimation of Genetic Parameters. The genetic parameters, mainly genotypic variance $\left(\sigma^{2} \mathrm{~g}\right)$, phenotypic variance $\left(\sigma^{2} \mathrm{p}\right)$, phenotypic coefficient of variation $(\mathrm{PCV})$, and genotypic coefficient of variation (GCV), were estimated using the formula mentioned elsewhere [22, 23].

2.7. Estimation of Heritability and Genetic Advance. Heritability illustrates the relative contributions of genetic and nongenetic differences to the overall phenotypic variation in the garlic germplasm. Since heritability estimates the genetic and environmental factors in the population relatively, heritability was calculated in the broadest sense for all characters using the formula and classified as low (below $40 \%$ ), medium (40-80\%), and high (above 80\%) [24].

$$
H^{2}=\frac{\sigma^{2} g}{\sigma^{2} p} \times 100,
$$

where $H^{2}$ is heritability in the broad sense, $\sigma^{2} g$ is genotypic variance, and $\sigma^{2} p$ is phenotypic variance.

Genetic advance (GA) is a measure of how much gain you may get from phenotypic selection for a trait. It mainly depends on the selection intensity ( $i=1.76$ at the $10 \%$ level), broad sense heritability $\left(H^{2}\right)$ of character, and the phenotypic standard deviation of the trait (measure of the phenotypic variability). Genetic advance (GA) and genetic advance as percentage of mean (GAM\%) were calculated according to the recommended method [20]. Genetic advance as percentage of mean (GAM) was classified as low, moderate, and high with $0-10 \%, 10-20 \%$, and $>20 \%$, respectively. The phenotypic and genotypic components of variance, as well as phenotypic and genotypic coefficients of variation, are calculated according to the proposed methods [24].

$$
\mathrm{GA}=(k) \sqrt{V p}\left(H^{2}\right),
$$

where $k=1.76$ (10\% selection intensity), $V p$ represents phenotypic variances, and $H^{2}$ is heritability.

2.7.1. Estimation of Correlation Coefficients. The genotypic and phenotypic correlation coefficients between yield and yield attributed traits were computed as described by $[25,26]$, respectively.

$$
\text { Genotypic correlation }=\frac{\operatorname{Cov}(g) 1.2}{\sqrt{\sigma} 2(g) 1 . \sigma 2(g) 2},
$$

where

$\operatorname{Cov}(g)(x y)$ is genotypic covariance between variables $X$ and $Y$

$\sigma 2(g) 1$ is genotypic variance of variable $X 1$

$X 1 \sigma 2(g) 2$ is genotypic variance of variable $X 2$

$$
\text { Phenotypic correlation }=\frac{\operatorname{Cov}(p h) 1.2}{\sqrt{\sigma} 2(p h) 1 . \sigma 2(p h) 2},
$$

where

Cov $(p h)(x y)$ is phenotypic covariance between variables $X$ and $Y$

$\sigma 2(p h) 1$ is phenotypic variance of variable $X 1$

$\sigma 2(p h) 2$ is phenotypic variance of variable $X 2$

\section{Results and Discussion}

3.1. Physicochemical Analysis of Experimental Soil. Soil tests are used to determine nutrient and contamination levels, composition, and other properties such as acidity or $\mathrm{pH}$. They can determine the fertility or expected growth potential of the soil, indicating nutrient deficiency, potential toxicities from excessive fertility, and inhibition from the presence of nonessential (trace) minerals. The texture of the test soil was clay, which consisted of $15.19 \%$ sand, $38.87 \%$ silt, and $45.94 \%$ clay. It also contained various minerals and ions that contribute to the growth and productivity of garlic accessions, as shown in Table 2.

3.2. Analysis of Variance. The mean squares due to accessions were highly significant for the examined morphological traits, suggesting the existence of genetic variations in 
TABLE 2: Physicochemical analysis of the experimental soil in EzoOtte in the Chencha district of Gamo highlands in southern Ethiopia in main cropping season, 2017.

\begin{tabular}{|c|c|}
\hline Parameter & Amount \\
\hline Texture class & Clay \\
\hline $\mathrm{P}^{\mathrm{H}}-\mathrm{H}_{2} \mathrm{O}(1: 2.5)$ & 7.90 \\
\hline $\mathrm{EC}(\mathrm{ms} / \mathrm{cm})(1: 2.5)$ & 1.57 \\
\hline Organic carbon (\%) & 1.63 \\
\hline Nitrogen $(\%)$ & 0.13 \\
\hline Available $P\left(\mathrm{mg} \mathrm{P}_{2} \mathrm{O}_{5} / \mathrm{kg}\right.$ soil $)$ & 66.87 \\
\hline Field capacity (FC) of soil ( 0.33 bar) (\%) & 35.61 \\
\hline Permanent wilting point (15 bar) $(\%)$ & 18.81 \\
\hline $\mathrm{Na}(\mathrm{meq} / \mathrm{l})$ & 0.60 \\
\hline $\mathrm{K}(\mathrm{meq} / \mathrm{l})$ & 0.18 \\
\hline $\mathrm{Ca}(\mathrm{meq} / \mathrm{l})$ & 2.00 \\
\hline $\mathrm{Mg}(\mathrm{meq} / \mathrm{l})$ & 1.40 \\
\hline $\mathrm{HCO}_{3}^{-1}(\mathrm{meq} / \mathrm{l})$ & 0.60 \\
\hline $\mathrm{Cl}^{-}(\mathrm{meq} / \mathrm{l})$ & 2.64 \\
\hline $\mathrm{SO}_{4}^{--}(\mathrm{meq} / \mathrm{l})$ & 0.39 \\
\hline $\mathrm{NO}_{3}(\mathrm{meq} / \mathrm{l})$ & 0.35 \\
\hline $\mathrm{Zn}$ (mg/kg soil) & 0.92 \\
\hline Mn (mg/kg soil) & 3.81 \\
\hline $\mathrm{Cu}$ (mg/kg soil) & 7.38 \\
\hline $\mathrm{Fe}(\mathrm{mg} / \mathrm{kg}$ soil $)$ & 8.99 \\
\hline
\end{tabular}

garlic. The significant mean sum of squares due to bulb yield and associated traits indicated the existence of considerable variability in the garlic accessions. The present finding agrees with the report mentioned elsewhere [27], which found enormous variability in Ethiopian garlic additions. Similarly, various studies expected great variability for the number of leaves per plant $(\mathrm{cm})$, leaf length $(\mathrm{cm})$, bulb diameter (equatorial) $(\mathrm{cm})$, bulb weight $(\mathrm{g})$, the number of cloves per bulb, clove weight $(\mathrm{g})$, and bulb yield (tons per hectare) $[12,28]$.

3.3. Mean Performance of Garlic Accessions. Garlic (Allium sativum L.) reproduces only through vegetative reproduction and shows considerable morphological differences within and between varieties [27]. This may be due to phenotypic plasticity and the presence of mutations that make the assessment and systematic classification of garlic problematic [29]. Therefore, analyzing the genetic diversity and the relationship between individuals is important for the improvement of garlic. Previous research analyzed the genetic diversity in Ethiopian garlic accessions collected at different locations and found that most traits vary widely [30]. Similarly, the morphological analysis in the present study also showed that the accessions function differently and exhibit great variability. One of the most important findings of the present study was the variability between the range accessions tested, the range results, and the mean. Maximum variability was observed for bulb yield per hectare and plant height. The highest seed yield (10.98 tons/hectare), bulb weight $(20.35 \mathrm{~g})$, bulb diameter (equatorial) (38.01), and clove weight $(3.4 \mathrm{~g}$ ) were obtained from G-8, G-12, and G-16, respectively (Table 3). The present results are in agreement with the results of previous research, which reported a wide range of variations in bulb yield and yield- related characteristics of garlic genotypes [12, 30]. These genotypes could be used as potential parents in a breeding program to improve bulb yield and its components.

\subsection{Estimation of Genetic Parameters and Heritability.} The estimates of genotypic variation $\left(\sigma^{2} g\right)$, phenotypic variation $\left(\sigma^{2} p\right)$, genotypic coefficient of variation $(\mathrm{GCV})$, phenotypic coefficient of variation (PCV), heritability $\left(\mathrm{H}^{2}\right)$, genetic progression (GA), and genetic progression as a percentage of the means (GAM) for various traits are shown in Table 4 . The component of phenotypic variance for all measured traits was further subdivided into genotypic variance $\left(\sigma^{2} g\right), G \times E$ variance $\left(\sigma^{2} g E\right)$, and error variance $\left(\sigma^{2} e\right)$. However, only genotypic variance was compared with total phenotypic variance to understand the extent of the genotypic contribution to the improvement of garlic. The present study confirmed that the highest genotypic variance and phenotypic variance were for days to maturity, bulb weight, and bulb diameter (equatorial). The extent of phenotypic variation was highest because it is a product of environmental and genetic variance. Furthermore, the evaluation of GCV, PCV, and heredity helps to assess the contribution of genes and the environment to the expression of each trait while facilitating a better and more effective selection for the plant breeder. In particular, values of the phenotypic coefficient of variance (PCV) and the genotypic coefficient of variance (GCV) above 20\%, between $10 \%$ and $20 \%$, and below $10 \%$ are considered high, medium, and low, respectively [21]. In the present study, all traits examined had a higher PCV than the GCV, suggesting an important role of the environment in the expression of traits (Table 4). Among all traits examined, high-to-moderate PCV and GCV were observed for yield per plant $((53.38 \%)$ and (46.8\%)), bulb diameter (equatorial) $((46,0 \%)$ and $(45.7 \%))$, number of leaves $((44.21 \%)$ and $(42.8 \%))$, and bulb weight $((42.75 \%)$ and $(42.6 \%))$, respectively. High PCV and GCV were observed for these traits, as mentioned elsewhere [30]. Moderate PCV and GCV were recorded for the number of seeds per plant. These results are largely in line with previous researchers $[21,24]$. The high-to-moderate values of PCV and GCV observed for the above traits in the present study indicated the existence of variability for the traits examined; and the high PCV and GCV traits mentioned above should allow reasonable scope for improvement by selection in the respective environments due to the modest genetic variability available in the germplasm collections evaluated [31]. However, low PCV and GCV have been recorded for maturity time (MT), and days of emergence (50\% germination) implies that the selection for these characters may not be effective. GCV was close to PCV in terms of plant height, the number of shoots per plant, leaf length, and days to maturity, suggesting that the environmental impact on the expression of these traits was small [23].

Heritability in a broad sense is important to the breeder, since it indicates the possibility and extent to which improvement is possible through selection. In the present investigation, estimates of broad sense heritability $\left(H^{2}\right)$ ranged from 72.1 to $99.37 \%$. The most intriguing finding is of 
TABLE 3: The mean performance of 28 garlic accessions in Ezo-Otte in the Chencha district of the Gamo highlands in southern Ethiopia in main cropping season, 2017.

\begin{tabular}{|c|c|c|c|c|c|c|c|c|c|c|c|}
\hline Code & GP & $\mathrm{PH}(\mathrm{cm})$ & $\mathrm{NL}$ & NSP & LL $(\mathrm{cm})$ & $\mathrm{BW}(\mathrm{g})$ & $\mathrm{BD}(\mathrm{mm})$ & $\mathrm{CN}$ & CW (g) & MT & BY (t/ha) \\
\hline G-1 & 18.00 & 35.05 & 14.33 & 27.16 & 38.12 & 40.50 & 37.06 & 10.37 & 3.07 & 139.25 & 10.98 \\
\hline G-2 & 17.00 & 33.61 & 15.33 & 22.16 & 25.12 & 38.80 & 35.80 & 11.33 & 2.80 & 134.25 & 9.13 \\
\hline G-3 & 18.50 & 33.74 & 9.00 & 17.66 & 22.62 & 37.87 & 35.28 & 11.50 & 2.42 & 141.91 & 8.51 \\
\hline G-4 & 21.01 & 27.22 & 9.07 & 20.50 & 21.62 & 30.86 & 27.60 & 11.00 & 1.46 & 150.33 & 6.22 \\
\hline G-5 & 23.50 & 25.08 & 6.93 & 24.66 & 24.62 & 29.22 & 24.41 & 11.51 & 0.88 & 137.25 & 5.61 \\
\hline G-6 & 21.83 & 29.20 & 11.00 & 26.83 & 26.62 & 36.34 & 33.83 & 12.73 & 2.42 & 129.25 & 8.55 \\
\hline G-7 & 18.17 & 30.65 & 16.33 & 26.66 & 28.63 & 35.98 & 32.96 & 14.50 & 2.25 & 127.25 & 8.06 \\
\hline G-8 & 22.80 & 24.80 & 12.33 & 28.66 & 18.62 & 20.89 & 18.57 & 12.67 & 0.89 & 118.25 & 4.55 \\
\hline G-9 & 15.50 & 25.17 & 15.33 & 32.66 & 27.50 & 24.47 & 21.50 & 12.01 & 1.36 & 135.25 & 5.30 \\
\hline G-10 & 21.00 & 23.87 & 10.33 & 30.66 & 31.63 & 20.87 & 19.58 & 10.90 & 1.09 & 121.25 & 4.65 \\
\hline G-11 & 20.00 & 24.22 & 13.33 & 28.66 & 18.62 & 21.96 & 18.50 & 13.00 & 1.33 & 141.25 & 5.88 \\
\hline G-12 & 18.66 & 23.79 & 14.50 & 26.83 & 22.62 & 20.35 & 18.67 & 12.67 & 0.95 & 137.25 & 4.85 \\
\hline G-13 & 17.00 & 21.60 & 11.33 & 28.66 & 22.63 & 20.51 & 18.88 & 13.67 & 0.88 & 110.25 & 4.65 \\
\hline G-14 & 20.83 & 24.10 & 13.33 & 33.67 & 27.62 & 20.93 & 19.66 & 11.67 & 1.16 & 134.25 & 4.58 \\
\hline G-15 & 20.00 & 23.58 & 14.33 & 25.66 & 18.63 & 23.67 & 19.66 & 13.07 & 1.01 & 142.25 & 4.87 \\
\hline G-16 & 22.50 & 35.55 & 16.00 & 22.00 & 34.63 & 40.85 & 38.01 & 16.20 & 3.40 & 128.25 & 10.55 \\
\hline G-17 & 17.50 & 35.75 & 11.00 & 31.00 & 31.63 & 38.26 & 34.65 & 15.00 & 2.59 & 133.25 & 9.68 \\
\hline G-18 & 22.50 & 36.28 & 11.33 & 31.67 & 30.63 & 36.20 & 33.10 & 9.67 & 2.31 & 126.25 & 8.22 \\
\hline G-19 & 17.50 & 32.31 & 13.33 & 24.66 & 37.63 & 35.50 & 31.87 & 11.83 & 2.22 & 143.25 & 7.94 \\
\hline G-20 & 18.50 & 24.63 & 10.00 & 26.66 & 25.63 & 30.33 & 26.97 & 15.67 & 1.18 & 146.25 & 6.05 \\
\hline G-21 & 21.00 & 33.58 & 9.90 & 27.66 & 33.62 & 36.30 & 33.07 & 10.33 & 2.69 & 125.25 & 8.55 \\
\hline G-22 & 18.00 & 31.65 & 10.60 & 22.66 & 30.62 & 34.77 & 32.35 & 14.37 & 2.24 & 131.25 & 7.42 \\
\hline G-23 & 14.50 & 29.61 & 15.33 & 25.66 & 20.62 & 34.79 & 32.41 & 14.27 & 2.17 & 122.58 & 7.32 \\
\hline G-24 & 19.50 & 24.31 & 12.33 & 18.66 & 24.62 & 24.08 & 21.55 & 13.00 & 1.62 & 127.25 & 6.49 \\
\hline G-25 & 23.00 & 22.57 & 16.33 & 24.66 & 26.63 & 21.17 & 16.94 & 12.83 & 1.08 & 124.25 & 10.50 \\
\hline G-26 & 18.00 & 25.40 & 17.33 & 26.66 & 17.62 & 25.36 & 22.07 & 10.17 & 1.58 & 132.25 & 6.63 \\
\hline G-27 & 18.55 & 22.85 & 19.33 & 22.66 & 18.62 & 24.13 & 21.66 & 10.53 & 1.21 & 120.25 & 5.32 \\
\hline G-28 & 19.66 & 23.38 & 21.33 & 24.00 & 24.63 & 23.00 & 20.86 & 12.73 & 1.05 & 137.25 & 5.43 \\
\hline CV (\%) & 12.03 & 3.38 & 10.96 & 5.59 & 3.35 & 3.38 & 4.85 & 11.24 & 12.58 & 1.12 & 25.59 \\
\hline SE & 5.46 & 0.89 & 2.09 & 2.14 & 0.78 & 0.99 & 1.67 & 1.96 & 0.05 & 2.20 & 3.22 \\
\hline
\end{tabular}

$\mathrm{GP}=50 \%$ germination time, $\mathrm{PH}$ is plant height, NL is number of leaf plants, NSP is number of shoots per plant, LL is leaf length, BW is bulb weight, $\mathrm{BD}$ is bulb diameter (equatorial), $\mathrm{CN}$ is clove number, $\mathrm{CW}$ is clove weight, MT is maturity time, BY is bulb yield (tons per hectare), and G is garlic accession.

TABLE 4: Estimation of the means, range, components of variance, PCV, GCV, $H^{2}$, GA, and GAM of the bulb yield and related traits of garlic accessions in Ezo-Otte in the Chencha district of the Gamo highlands in southern Ethiopia in main cropping season, 2017.

\begin{tabular}{lcccccccccccc}
\hline \multirow{2}{*}{ Traits } & \multirow{3}{*}{ Mean } & \multicolumn{3}{c}{ Range } & \multicolumn{3}{c}{ Variance } & \multicolumn{3}{c}{ Coefficient of variation } & \multirow{2}{*}{$H^{2}(\%)$} & \multirow{2}{*}{ GA } \\
& & Maximum & Minimum & Geno. & Env. & Pheno. & Geno. & Env. & Pheno. & & \\
\hline GP & 19.39 & 27.00 & 12.00 & 14.11 & 5.44 & 19.55 & 72.78 & 28.04 & 100.81 & 72.19 & 5.62 & 28.97 \\
PH & 27.99 & 37.01 & 21.20 & 70.38 & 0.89 & 71.27 & 251.47 & 3.20 & 254.67 & 98.75 & 14.67 & 52.42 \\
NL & 13.19 & 23.00 & 6.00 & 31.92 & 2.09 & 34.01 & 241.99 & 15.85 & 257.84 & 93.85 & 9.63 & 73.03 \\
NSP & 26.17 & 35.00 & 16.00 & 46.89 & 2.14 & 49.03 & 179.15 & 8.19 & 187.33 & 95.63 & 11.79 & 45.03 \\
LL & 26.12 & 39.00 & 16.75 & 99.20 & 0.77 & 99.97 & 379.79 & 2.94 & 382.73 & 99.23 & 17.46 & 66.85 \\
BW & 29.54 & 41.50 & 19.24 & 158.50 & 1.00 & 159.50 & 536.59 & 3.38 & 539.97 & 99.37 & 22.09 & 74.78 \\
BD & 26.66 & 38.50 & 11.10 & 148.46 & 1.67 & 150.13 & 556.93 & 6.26 & 563.19 & 98.89 & 21.33 & 80.00 \\
CN & 12.46 & 17.00 & 8.00 & 7.86 & 1.96 & 9.82 & 63.08 & 15.73 & 78.81 & 80.04 & 4.41 & 35.43 \\
CW & 1.75 & 3.60 & 0.78 & 1.63 & 0.05 & 1.68 & 92.93 & 2.78 & 95.70 & 97.10 & 2.21 & 126.30 \\
MT & 132.10 & 151.00 & 109.50 & 256.85 & 2.20 & 259.05 & 194.44 & 1.67 & 196.11 & 99.15 & 28.09 & 21.26 \\
BY & 7.01 & 21.00 & 4.13 & 10.79 & 3.22 & 14.01 & 153.88 & 45.93 & 199.81 & 77.01 & 5.07 & 72.35 \\
\hline
\end{tabular}

$\mathrm{GP}=50 \%$ germination time, $\mathrm{PH}$ is plant height, NL is number of leaf plants, NSP is number of shoots per plant, LL is leaf length, BW is bulb weight, BD is bulb diameter (equatorial), $\mathrm{CN}$ is clove number, $\mathrm{CW}$ is clove weight, MT is maturity time, BY is bulb yield (tons per hectare), PCV is phenotypic coefficient of variation, GCV is genotypic coefficient of variation, $H^{2}$ is heritability in broad sense, GA is genetic advance, and GAM is genetic advance as percentage of mean.

the present high (80\%) heritability in broad sense which was recorded for most of the morphological descriptors considered in the study. This suggests that a good match between genotypic and phenotypic values and thereby a low environmental impact on the expression of these traits and selection for these traits would be fairly easy. The character's high heritability is controlled by polygenes, which could be useful for plant breeders to make effective choices [12]. 
TABLE 5: Genotypic and phenotypic correlation coefficients of bulb yield and related traits of garlic accessions in in Ezo-Otte in the Chencha district of the Gamo highlands in southern Ethiopia in main cropping season, 2017.

\begin{tabular}{|c|c|c|c|c|c|c|c|c|c|c|c|}
\hline Parameter & GP & $\mathrm{PH}$ & NL & NSP & LL & BW & $\mathrm{BD}$ & $\mathrm{CN}$ & CW & MT & BY \\
\hline GP (G) & & -0.09134 & -0.25595 & 0.05078 & 0.03108 & -0.14928 & -0.15849 & -0.16532 & -0.15085 & -0.02726 & -0.07856 \\
\hline (P) & & 0.4086 & 0.0188 & 0.6465 & 0.7789 & 0.1753 & 0.1499 & 0.1329 & 0.1708 & 0.8055 & 0.4775 \\
\hline $\mathrm{PH}(\mathrm{G})$ & & & -0.20165 & -0.06365 & 0.60949 & 0.91427 & 0.91282 & -0.02937 & 0.89702 & 0.13440 & 0.62853 \\
\hline$(\mathrm{P})$ & & & 0.0659 & 0.5651 & $<0.0001$ & $<0.0001$ & $<0.0001$ & 0.7909 & $<0.0001$ & 0.2229 & $<0.0001$ \\
\hline NL (G) & & & & -0.11005 & -0.20088 & -0.22218 & -0.20674 & -0.02191 & -0.05946 & -0.14509 & 0.05559 \\
\hline (P) & & & & 0.3190 & 0.0669 & 0.0422 & 0.0592 & 0.8432 & 0.5911 & 0.1879 & 0.6155 \\
\hline NSP (G) & & & & & 0.21973 & -0.20873 & -0.19773 & -0.01084 & -0.15304 & -0.21174 & -0.21206 \\
\hline$(\mathrm{P})$ & & & & & 0.0446 & 0.0567 & 0.0714 & 0.9220 & 0.1646 & 0.0532 & 0.0528 \\
\hline LL $(G)$ & & & & & & 0.54831 & 0.55392 & -0.01911 & 0.57712 & 0.05527 & 0.43934 \\
\hline (P) & & & & & & $<0.0001$ & $<0.0001$ & 0.8630 & $<0.0001$ & 0.6175 & $<0.0001$ \\
\hline BW (G) & & & & & & & 0.97954 & 0.07143 & 0.89909 & 0.21374 & 0.62391 \\
\hline$(\mathrm{P})$ & & & & & & & $<0.0001$ & 0.5185 & $<0.0001$ & 0.0509 & $<0.0001$ \\
\hline $\mathrm{BD}(\mathrm{G})$ & & & & & & & & 0.08873 & 0.89221 & 0.17136 & 0.62662 \\
\hline (P) & & & & & & & & 0.4222 & $<0.0001$ & 0.1191 & $<0.0001$ \\
\hline $\mathrm{CN}(\mathrm{G})$ & & & & & & & & & 0.02333 & -0.01537 & 0.06766 \\
\hline (P) & & & & & & & & & 0.8331 & 0.8896 & 0.5408 \\
\hline CW (G) & & & & & & & & & & 0.06588 & 0.66160 \\
\hline (P) & & & & & & & & & & 0.5516 & $<0.0001$ \\
\hline MT (G) & & & & & & & & & & & 0.04335 \\
\hline$(\mathrm{P})$ & & & & & & & & & & & 0.6954 \\
\hline
\end{tabular}

$\mathrm{GP}=50 \%$ germination time, $\mathrm{PH}$ is plant height, NL is number of leaf plants, NSP is number of shoots per plant, LL is leaf length, BW is bulb weight, BD is bulb diameter (equatorial), $\mathrm{CN}$ is clove number, CW is clove weight, MT is maturity time, BY is bulb yield (tons per hectare), G: genotypic, and P: phenotypic.

However, these results are in contrast with the data that have reported low inheritance in the number of leaves per plant and the height of the plant height [12]. This may be due to the variation in the test design, the plant material, and the geographical location of the test site. Heritability alone does not indicate the degree of genetic improvement that would result from the selection of an individual genotype, and the effectiveness of selection depends on heritability but genetic advance (GA) [31]. Hence, knowledge of heredity coupled with genetic advance is more useful. In addition, GA is important in predicting the expected genetic gain from a selection cycle [32]. In the present study, a high genetic advance was observed for days to maturity $(28,09)$, bulb weight $(22,09)$, and bulb diameter (equatorial) $(21,33)$. Overall, the progress of genetic progression and genetic advance as a percentage of the mean was higher for days to maturity, clove weight, clove number, bulb weight, bulb diameter (equatorial) (equatorial), and yield per plant. This argument is consistent with the findings mentioned elsewhere [12, 24].

A relative comparison of heritability along with genetic advance as a percentage of the means over the traits showed that clove weight had high heritability, combined with moderate genetic advance as a percentage of the mean indicating genotypic variations for such a trait. The dominance of the additive gene can be attributed to the pressure of action, and selection could profitably be applied to this character to improve the bulb yield. Furthermore, the highest heritability was observed with moderate GA as a percentage of the mean bulb weight and moderate heritability with high GA for days to maturity. Similar results of high heritability with moderate genetic advance as a percentage of the mean were recorded in these traits $[24,28]$.
These results confirmed that these characters were primarily controlled by the additive nature of the genes and that direct selection for these traits could be effective. However, high heritability associated with low GA was observed for plant yield. Thus, this trait is controlled by nonadditive genes (dominance and epistasis), so environmental control on the expression of these traits and their improvement could be achieved by heterosis breeding [12].

3.5. Bulb Yield and Associated Traits for Garlic Accessions. Correlation analysis helps evaluate the relationship between yield and its components. Phenotypic and genotypic correlation coefficients of bulb/plant yield with other characters are presented in Table 5. The phenotypic correlation showed that the plant yield correlated highly positively and significantly with $50 \%$ germination time $(r=0.4775)$, number of leaves $(r=0.61550)$, number of shoots per plant $(r=0.0528)$, number of cloves $(r=0.5408)$, and days to maturity (0.6954). Furthermore, the genotypic correlation showed that the plant yield was very positively and significantly correlated with the weight of the cloves $(r=0.6616)$, the number of cloves $(r=0.6766)$, and the height of the plant height $(r=0.62853)$. However, $50 \%$ germination percentage $(-0.07856)$ and the number of shoots per plant $(-0.21206)$ were negatively correlated with the plant yield (tons per hectare). The results showed that the magnitude of the genotypic correlation coefficients was higher than their phenotypic correlation coefficients, suggesting the absence of environmental influences that reinforce genetic inherent associations [33]. Bulb yield highly significantly correlated with plant height, leaf length, bulb diameter (equatorial), 
bulb weight, and clove weight. This is an interesting finding and could be suspected. Therefore, more importance should be given to these traits at the time of selection to improve bulb yield [23].

\section{Conclusion}

The range and mean of agronomic traits obtained in this study indicated that there was great variability between garlic accessions. Heritability in broad sense estimates, genetic advance, and genetic advance as a percentage of the mean was high on bulb weight, bulb diameter (equatorial) (equatorial), clove weight, number of cloves, and days to maturity, and coefficient analysis showed that it positively significantly correlated with bulb yield (tons per hectare). Therefore, more importance should be devoted to these traits in the selection process to improve garlic production.

\section{Data Availability}

The data used to support the findings of this study are available from the corresponding author upon reasonable request.

\section{Disclosure}

The funder played no role in study design, data collection, or management of any research activity.

\section{Conflicts of Interest}

The author declares that there are no conflicts of interest regarding the publication of this article.

\section{Acknowledgments}

The author would like to express sincere gratitude to Arba Minch University for providing financial support to undertake this study. The author is very grateful to Debre Zeit Agricultural Research Center for providing garlic accessions suitable for the study. Finally, the efforts of all people who directly or indirectly backed carrying out this piece of work are highly appreciated. This research was funded by Arba Minch University.

\section{References}

[1] L. A. Egea, R. Mérida-García, A. Kilian, P. Hernandez, and G. Dorado, "Assessment of genetic diversity and structure of large garlic (Allium sativum) germplasm bank, by diversity arrays technology "genotyping-by-sequencing" platform (DArTseq)," Frontiers in Genetics, vol. 8, p. 98, 2017.

[2] A. Ayalew, D. Tadesse, Z. G. Medhin, and S. Fantaw, "Evaluation of garlic (Allium sativum L.) varieties for bulb yield and growth at dabat, northwestern Ethiopia," OALib, vol. 2, no. 1, pp. 1-5, 2015.

[3] R. Ahmad, "Assessment of genetic divergence and its utilization in hybrid development in cultivated onion (Allium cepa L.)," Journal of Animal and Plant Sciences, vol. 31, no. 1, pp. 175-187, 2021.
[4] A. Tesfaye and W. Mengesha, "Traditional uses, phytochemistry and pharmacological properties of garlic (Allium Sativum) and its biological active compounds," International Journal of Scientific Research in Science, Engineering and Technology, vol. 1, pp. 142-148, 2015.

[5] S. Kaushik, M. Kumar, S. Prakash et al., "Study of genetic diversity in garlic (Allium sativum L.) by using morphological characters," Progressive Agriculture, vol. 16, no. 2, pp. 204-210, 2016.

[6] H. Wang, X. Li, D. Shen, Y. Oiu, and J. Song, "Diversity evaluation of morphological traits and allicin content in garlic (Allium sativum L.) from China," Euphytica, vol. 198, no. 2, pp. 243-254, 2014.

[7] Y. Yeshiwas, "Collection and characterization of garlic ( $\mathrm{Al}$ lium sativm L.) germplasm for growth and bulb yield at Debre Markos, Ethiopia," Journal of Horticulture and Forestry, vol. 10, no. 3, pp. 17-26, 2018.

[8] A. A. A. O. E. Hussein, "Morphological and analytical characterization of moringa peregrine populations in western Saudi arabia," International Journal of Theoretical and Applied Finance, vol. 4, no. 20, pp. 187-184, 2012.

[9] K. Jannat, T. Rahman, and M. Rahmatullah, "Traditional uses, phytochemicals and pharmacological properties of allium tuberosum rottler ex spreng," Journal of Medicinal Plants Studies, vol. 7, pp. 214-220, 2019.

[10] E. A. Brisibe, U. E. Umoren, F. Brisibe et al., "Nutritional characterisation and antioxidant capacity of different tissues of Artemisia annua L," Food Chemistry, vol. 115, no. 4, pp. 1240-1246, 2009.

[11] N. Jabbes, I. Arnault, J. Auger, B. Al Mohandes Dridi, and C. Hannachi, "Agro-morphological markers and organosulphur compounds to assess diversity in Tunisian garlic landraces," Scientia Horticulturae, vol. 148, pp. 47-54, 2012.

[12] M. C. Ranjitha, M. A. Vaddoria, and A. S. Jethava, "Genetic variability, heritability and genetic advance in garlic (Allium sativum L.) germplasm," International Journal of Pure \& Applied Bioscience, vol. 6, no. 4, pp. 401-407, 2018.

[13] G. M. Volk and D. Stern, "Phenotypic characteristics of ten garlic cultivars grown at different North American locations," HortScience, vol. 44, no. 5, pp. 1238-1247, 2009.

[14] S. Jafari, M. R. Hassandokht, M. Taheri, and A. Kashi, "Genetic diversity and taxonomic studies of Allium akaka and A. elburzense native to Iran using morphological characters," Journal of Horticultural Research, vol. 25, no. 1, pp. 99-115, 2017.

[15] C. Ayed, "Morphological evaluation of tunisian garlic (Allium sativum L.) landraces for growth and yield traits," Journal of Horticulture and Postharvest Research, vol. 2, no. 1, pp. 43-52, 2019.

[16] E. S. S. Hoogerheide, J. A Azevedo Filho, R Vencovsky, M. I Zucchi, B. W Zago, and J. B Pinheiro, "Genetic variability of garlic accessions as revealed by agro-morphological traits evaluated under different environments," Genetics and Molecular Research: GMR, vol. 16, no. 2, 2017.

[17] M. S. Adem, "Environmental knowledge, attitude and awareness of farmers in chencha woreda, gamo gofa zone, South Ethiopia," International Journal of Scientific and Research Publications, vol. 7, no. 1, pp. 69-76, 2017.

[18] W. M. Dersseh, Y. T. Gebresilase, R. P. O. Schulte, and P. C. Struik, "The analysis of potato farming systems in chencha, Ethiopia: input, output and constraints," American Journal of Potato Research, vol. 93, no. 5, pp. 436-447, 2016.

[19] N. Polyzos, V. Papasotiropoulos, F. N. Lamari, S. A. Petropoulos, and P. J. Bebeli, "Phenotypic 
characterization and quality traits of greek garlic (Allium sativum L.) germplasm cultivated at two different locations," Genetic Resources and Crop Evolution, vol. 66, no. 8, pp. 1671-1689, 2019.

[20] IPGRIE, GRA, Descriptors for Allium (Allium spp.), International Plant Genetic Resources Institute, Rome, Italy, 2001.

[21] H. Raja, "Genetic variability assessment in garlic (Allium sativum L.) genotypes," Journal of Pharmacognosy and Phytochemistry, vol. 6, no. 6, pp. 1781-1786, 2017.

[22] C. Neelima, "Estimation of variability, heritability, genetic advance and assessment of frequency distribution for morphological traits in intercross population of maize," Electronic Journal of Plant Breeding, vol. 11, no. 2, pp. 574-580, 2020.

[23] D. N. Tiwari, "Genetic variability and correlation coefficients of major traits in early maturing rice under rainfed lowland environments of Nepal," Advances in Agriculture, vol. 2019, Article ID 5975901, 9 pages, 2019.

[24] Y. Yeshiwas and B. Negash, "Genetic variability, heritability and genetic advance of growth and yield components of garlic (Allium sativm L.) germplasms," Journal of Biology, Agriculture and Healthcare, vol. 7, no. 21, pp. 2224-3208, 2017.

[25] B. D. Bekele, "Estimation of genetic variability and correlation studies for grain zinc concentrations and yield related traits in selected rice (Oryza sativa L.) genotypes," Asian Journal of Experimental Biological Sciences, vol. 4, no. 3, pp. 345-351, 2013.

[26] B. Singh, Plant Breeding: Principles and Methods, Kalyani Publishers, New Delhi, India, 6th edition, 2001.

[27] R. K. Singh, B. K. Dubey, and R. P. Gupta, "Studies on variability and genetic divergence in elite lines of garlic (Allium sativum L.)," Journal of Spices and Aromatic Crops, vol. 21, no. 2, 2012.

[28] R. Panse, "Morphological variability and character association in diverse collection of garlic germplasm," African Journal of Agricultural Research, vol. 8, no. 23, pp. 2861-2869, 2013.

[29] M. H. Jo, "Classification of genetic variation in garlic ("Allium sativum" L.) using SSR markers," Australian Journal of Crop Science, vol. 6, no. 4, pp. 625-631, 2012.

[30] G. Atinafu, "Morphological characterization and evaluation of garlic (Allium sativum L.) accessions collected from northern highlands of Ethiopia," ACST, vol. 9, no. 474, p. 2, 2021.

[31] S. R. Rathva, "Studies genetic variability, heritability and genetic advance for various yield contributing traits in garlic (Allium sativum L.)," Journal of Pharmacognosy and Phytochemistry, vol. 7, no. 5, pp. 1794-1797, 2018.

[32] A. Hamdi, A. A. El-Ghareib, S. A. Shafey, and M. A. M. Ibrahim, "Genetic variability, heritability, and expected genetic advance for earliness and seed yield from selection in lentil," Egypt Journal of Agriculture Research, vol. 18, pp. 125-137, 2003.

[33] K. Nanda, D. N. Bastia, and A. Nanda, "Character association and path coefficient analysis for yield and its component traits in slender grain rice (Oryza sativa L.)," Electronic Journal of Plant Breeding, vol. 10, no. 3, pp. 963-969, 2019. 